\title{
JOURNAL.RU
}

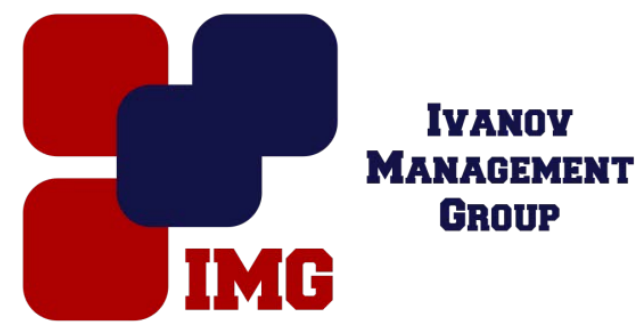

Афанасова О.С. ФГБОУ ВПО «Государственный университет управления» Москва, Россия

doi: 10.18411/lj-30-11-2016-2-01

idsp 000001:lj-30-11-2016-2-01

\section{О введении единого социального страхового сбора}

\section{Аннотация:}

Освещена сущность единого социального страхового сбора, уделено внимание причинам введения единого социально страхового сбора,указаны изменения в нормативных актах в связи с введением единого страхового социального сбора. Перечислены основные изменения в отчетности в связи с введением единого социально страхового сбора. Рассмотрены основные трудности, связанные с введением единого социального страхового сбора.

Ключевые слова: единый социальный страховой сбор, страховая реформа, взносы в фонды, налоговые органы, выездные и камеральные налоговые проверки.

\section{Введение единого социальный страхового сбора}

С 1 января 2017 года все компании и предприниматели будут обязаны платить единый социальный страховой сбор (далее - ЕССС).

Единый социальный страховой сбор - это единый сбор, который полностью заменит взносы на обязательное пенсионное страхование, на обязательное медицинское страхование и на обязательное социальное страхование на случай временной нетрудоспособности и в связи с материнством. В настоящий момент все вышеперечисленные взносы организации и предприниматели платят в различные фонды. Взносы на обязательное пенсионное страхование платят в Пенсионный фонд РФ, на обязательное медицинское страхование в Фонд обязательного медицинского страхования, на обязательное социальное страхование на случай временной нетрудоспособности и в связи с материнством в Фонд социального страхования. Новый же единый социальный страховой сбор будет централизованно собирать и распределять Федеральная налоговая служба, за исключением взносов на обязательное социальное страхование от несчастных случаев на производстве и профессиональных заболеваний. Данным видом взносов на обязательное 
социальное страхование от несчастных случаев на производстве и профессиональных заболеваний по-прежнему будет заниматься фонд социального страхования РФ. ЕССС организации будут перечислять на единый КБК, который должны утвердить 1 декабря 2016 года.

Данную реформу страховых взносов подготовила Федеральная налоговая служба по поручению Президента Российской Федерации. И этот документ называется «Дорожная карта создания единого механизма администрирования страховых взносов...». Данная реформа необходима для того, чтобы укрепить платежную дисциплину населения, усовершенствовать порядок исчисления и уплаты взносов, а такжеповысить собираемость взносов, что особенно актуально в условиях текущего кризиса.

Благодаря реформе социальных взносов большое количество нормативных документов пришлось изменить. Больше всех изменений претерпел Налоговый кодекс. Например, был добавлен новый одиннадцатый раздел под названием «страховые взносы в Российской Федерации», а в нем новая тридцать четвертая глава «Страховые взносы». Также везде в первом разделе к «налогам и сборам» приписали фразу «страховые взносы». Претерпел изменения Кодекс Российской Федерации об административных правонарушениях.

А с 1 января 2017 года полностью утратит силу Федеральный закон от 24 июля 2009 года № 212-Ф3 «О страховых взносах в Пенсионный фонд Российской Федерации, Фонд социального страхования Российской Федерации, Федеральный фонд обязательного медицинского страхования».

Также изменения были внесены в следующие Федеральные законы:

- Федеральный закон РФ от 21 марта 1991 года № 943-I «О налоговых органах Российской Федерации»;

- Федеральный закон от 1 апреля 1996 года № 27-Ф3 «Об индивидуальном (персонифицированном) учете в системе обязательного пенсионного страхования»;

- Федеральный закон от 24 июля 1998 года № 125-Ф3 «Об обязательном социальном страховании от несчастных случаев на производстве и профессиональных заболеваний»;

- Федеральный закон от 16 июля 1999 года № 165-Ф3 «Об основах обязательного социального страхования»;

- Федеральный закон от 15 декабря 2001 года № 167-Ф3 «Об обязательном пенсионном страховании в Российской Федерации»;

- Федеральный закон от 29 декабря 2006 года № 255-Ф3 «Об обязательном социальном страховании на случай временной нетрудоспособности и в связи с материнством»;

- Федеральный закон от 29 ноября 2010 года № 326-Ф3 «Об обязательном медицинском страховании в Российской Федерации»;

- Федеральный закон от 28 декабря 2013 года № 400-Ф3 «О страховых пенсиях»; 
- Другие.

Отчетность по единому социальному страховому взносу с 2017 года организации и предприниматели должны представлять в налоговые органы каждый квартал не позднее 15 числа текущего месяца, следующего за отчетным периодом. Если среднесписочная численность сотрудников организации свыше 25 человек, то отчетность необходимо представлять только в электронном виде через телекоммуникационные каналы связи. Также некоторые сведения будет необходимо передавать в ФСС и ПФР.

В Пенсионный фонд необходимо передавать данные о стаже застрахованных лиц раз в год, в срок не позднее 1 марта года, следующего за отчетным. Сведения о застрахованных лицах (форма СЗВ-М) необходимо предоставлять ежемесячно не позднее 15 числа месяца, следующего за отчетным.

В Фонд социального страхования необходимо передавать сведения по страховым взносам на обязательное социальное страхование от несчастных случаев на производстве и профессиональных заболеваниях.

До 1 января 2017 года контроль за правильностью исчислений взносов остается за фондами, после 1 января все функции по контролю и взысканию будут переданы в ФНС. Все данные по недоимкам будут переданы в налоговые органы. Начиная с 1 января органы ФНС будут проводить выездные и камеральные проверки уточненной отчетности по обязательствам плательщиков страховых взносов, возникшим до 1 января 2017 года.

До 1 марта 2017 года налоговые органы должны получить информацию о реестрах плательщиков страховых взносов, о реестрах застрахованных физических лиц, предварительное сальдо расчетов плательщиков страховых взносов по итогам 2016 года, акты сверки задолженности плательщиками за 2016 год.

Страховая реформа является одной из самых крупных и важных реформ страны за последние 10 лет. Она позволит повысить собираемость взносов и централизовать систему сбора взносов. В начале 2017 года возможны проблемы с обменом информацией между фондами и налоговыми органами, в частности, с передачей данных о недоимках и переплате взносов, а также с подтверждением расходов по пособиям. Если же в 2014 - 2016 годах организацию проверял Пенсионный фонд, то налоговые органы имеют право провести проверку еще раз. И эта проверка не будет считаться повторной. 


\section{Литература}

1. Налоговый кодекс РФ от 31 июля 1998 года N 146-ФЗ(в ред. Федерального закона от 29.11.2014 № 382-Ф3). Доступ из справ.правовой системы «Консультант Плюс».

2. Кодекс об административных правонарушениях РФ от $30.12 .2001 \mathrm{~N}$ 195-ФЗ (ред. от 06.07.2016) (с изм. и доп., вступ. в силу с 03.10.2016). Доступ из справ.-правовой системы «Консультант Плюс».

3. Письмо ФНС России от 02.02.2016 N БС-4-11/1539 "О проекте Дорожной карты". Доступ из справ.-правовой системы «Консультант Плюс».

4. Федеральный закон от 24 июля 2009 года № 212-Ф3 «О страховых взносах в Пенсионный фонд Российской Федерации, Фонд социального страхования Российской Федерации, Федеральный фонд обязательного медицинского страхования». Доступ из справ.-правовой системы «Консультант Плюс».

5. Федеральный закон РФ от 21 марта 1991 года № 943-I «О налоговых органах Российской Федерации». Доступ из справ.-правовой системы «Консультант Плюс».

6. Федеральный закон от 1 апреля 1996 года № 27-Ф3 «Об индивидуальном (персонифицированном) учете в системе обязательного пенсионного страхования». Доступ из справ.-правовой системы «Консультант Плюс».

7. Федеральный закон от 24 июля 1998 года № 125-ФЗ «Об обязательном социальном страховании от несчастных случаев на производстве и профессиональных заболеваний». Доступ из справ.-правовой системы «Консультант Плюс».

8. Федеральный закон от 16 июля 1999 года № 165-Ф3 «Об основах обязательного социального страхования». Доступ из справ.-правовой системы «Консультант Плюс».

9. Федеральный закон от 15 декабря 2001 года № 167-Ф3 «Об обязательном пенсионном страховании в Российской Федерации». Доступ из справ.-правовой системы «Консультант Плюс».

10. Федеральный закон от 29 декабря 2006 года № 255-Ф3 «Об обязательном социальном страховании на случай временной нетрудоспособности и в связи с материнством». Доступ из справ.правовой системы «Консультант Плюс».

11. Федеральный закон от 29 ноября 2010 года № 326-Ф3 «Об обязательном медицинском страховании в Российской Федерации». Доступ из справ.-правовой системы «Консультант Плюс».

12. Федеральный закон от 28 декабря 2013 года № 400-Ф3 «О страховых пенсиях». Доступ из справ.-правовой системы «Консультант Плюс». 
13. Указ Президента РФ от 15.01.2016 N 13 "О дополнительных мерах по укреплению платежной дисциплины при осуществлении расчетов с Пенсионным фондом Российской Федерации, Фондом социального страхования Российской Федерации и Федеральным фондом обязательного медицинского страхования". Доступ из справ.-правовой системы «Консультант Плюс».

14. План-график мероприятий («дорожная карта») по передаче полномочий по администрированию страховых взносов на обязательное пенсионное страхование и обязательное медицинское страхование органами Пенсионного фонда Российской Федерации налоговым органам от 05.09.2016. Доступ из справ.-правовой системы «ГАРАНТ». 